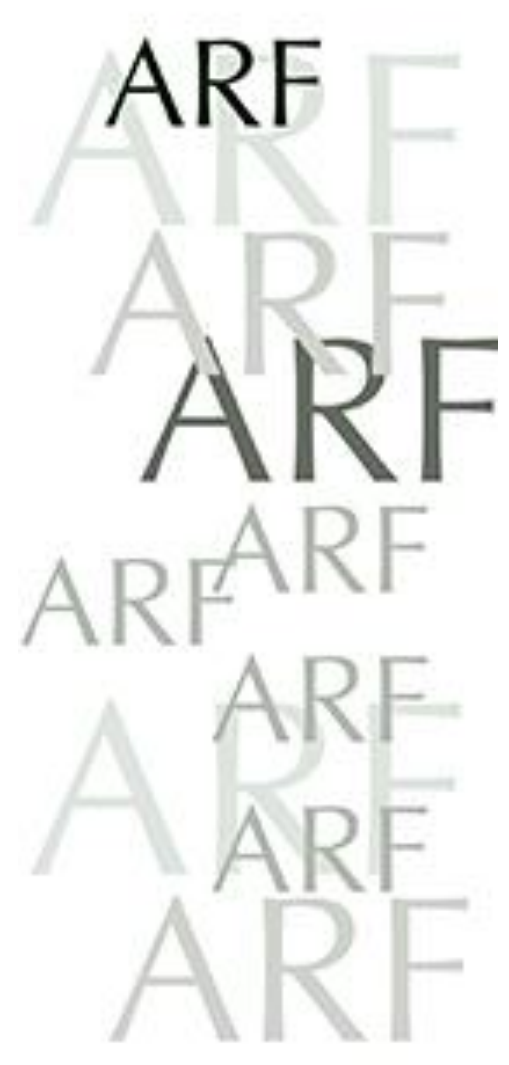

\title{
Osallistava suunnittelu supistuvien kuntien taajamien kehittämisessä
}

\author{
Jonna Taegen \\ Aalto University \\ jonna.taegen@aalto.fi \\ Tuula Kivinen \\ University of Eastern Finland \\ tuula.kivinen@uef.fi
}

\section{Tiivistelmä}

Suomen väestönkasvu on viime vuosikymmenten aikana keskittynyt yhä enemmän muutamille suurille kaupunkiseuduille. Samaan aikaan valtaosa maamme kunnista on menettänyt väestöään. Vuonna 2019 asukasluku pieneni 256 kunnassa ja kasvoi vain 54 kunnassa. Kehityskulun ennustetaan jatkuvan ja voimistuvan tulevaisuudessa. Kuntien asukasluvun väheneminen ilmenee muutoksena taajamarakenteessa. Palveluita katoaa, rakennuksia tyhjenee ja infrastruktuurin ylläpito heikentyy kuntien taloudellisen tilanteen kiristyessä. Kehityksellä on myös vaikutus paikallisten asukkaiden arkeen ja sosiaalisiin kontakteihin.

Kuntien väestökadon jatkuessa tarvitaan lisää tietoa siitä, miten yhdyskunta- ja rakennussuunnittelun keinoin nykyistä taajamarakennetta voidaan kehittää vastaamaan muuttuneita tarpeita. Tutkimuksen tarkoituksena on kuvata vakituisten ja vapaa-ajan asukkaiden näkemyksiä väestöltään supistuvien kuntien taajamien nykytilasta ja kehittämismahdollisuuksista. Tapaustutkimuksen taajamat ovat alle 10000 asukkaan taajamia. Laadullisessa tutkimuksessa etsitään vastauksia seuraaviin kysymyksiin: Mitä palveluita asukkaat pitävät tärkeinä omassa taajamassaan? Mitä palveluita he käyttävät naapurikunnissa? Mikä on parasta omassa kunnassa ja mitä asioita tulisi kehittää? Miten asukkaat haluaisivat osallistua oman taajamansa kehittämiseen? Aineisto hankittiin kolmen eri kunnan asukkaille suunnatulla kyselytutkimuksella. Kyselyyn oli mahdollista vastata verkossa tai paperilomakkeella. Vastauksia saatiin yhteensä 1052 kappaletta.

Kyselyn tuloksista kävi ilmi oman taajaman palveluiden merkitys asukkaille sekä pitkien asiointimatkojen vaikutus asukkaiden arkeen. Vastaajat toivat myös esille huollettujen ja viihtyisien sisä- ja ulkotilojen tärkeyden. Tilojen ja palveluiden käyttö on väestöltään vähenevissä kunnissa usein kausiluonteista. Monipaikkainen asuminen on sekä mahdollisuus että haaste kunnille. Vakituisten ja vapaa-ajan asukkaiden osallistumista taajaman kehittämistoimiin tulisi tukea ja kannustaa. Kyselytutkimuksesta ilmenee, että osallistuminen ja myös halu osallistua on yksilöllistä. Asukkaat ja heidän omaehtoinen työnsä asuinympäristön kehittämisessä on väestöltään vähenevien kuntien resurssi, jota tulisi hyödyntää vahvemmin.

Avainsanat: väestönmuutokset, taajamat, yhdyskuntasuunnittelu, osallisuus 


\section{Abstract}

\section{Participative approach for developing population centres of shrink- ing municipalities}

Over the last decades, Finland's population growth is centred on a few urban areas. At the same time most of the Finnish municipalities are losing population. In the year 2019 population diminished in 256 and grew in 54 municipalities. Based on population forecast, the same development is expected to continue in the future. Population decline has an impact on the urban structure of the population centres. Services disappear, buildings are abandoned and maintenance of infrastructure becomes insufficient due to the weak financial resources of the municipality. The development has also an impact on the local inhabitants and their everyday life and social contacts.

Since the population decline will continue in future, there is a need for more information about urban planning and building design methods to respond to the changing demands of population centres. The objective of the research is to describe the residents and second home owners' perception of the current situation and the development possibilities of shrinking municipalities. The case study focuses on population centres with less than 10000 inhabitants. The qualitative research seeks answers to the following questions: What services are important for the residents in their own population centre? What services do the residents use in the neighbourhood municipalities? What do the residents value most in the municipality and what needs to be developed? How would the residents like to be involved in the development of their own population centre? The material was compiled through a questionnaire survey to inhabitants and second home owners of three municipalities. It was possible to fill the survey out by paper or online. A total of 1052 responses were received.

The results of the survey show how meaningful the services of the own population centre are for the residents and how long distances to services affect the everyday life of the inhabitants. The respondents emphasized as well the importance of well-maintained and cosy indoor and outdoor spaces. The use of spaces and services is often seasonal in shrinking municipalities. Multilocality is both an opportunity and a challenge to the small municipalities. It is important to encourage residents and second home owners to participate in the development activities of their population centre. Nevertheless, the participation and the willingness to participate has proven to be individual. The residents and their spontaneous work for the development of the neighbourhood is a resource that could be utilised more in the shrinking municipalities.

Keywords: demographic changes, population centres, urban planning, participation 


\section{Johdanto}

Suomessa on 19 maakuntaa ja 310 kuntaa. Asukasluku kasvoi vuonna 2019 vain viidessä maakunnassa ja 54 kunnassa. (SVT, Väestörakenne 2019) Tuoreen väestöennusteen mukaan alueiden eriytyminen kasvaviin ja supistuviin alueisiin tulee jatkumaan. Vuonna 2040 asukasluvun ennustetaan kasvavan enää Uudenmaan ja Ahvenanmaan maakunnissa. (SVT, Väestöennuste 2019) Kunnat menettävät väestöään nopeammin ja voimakkaammin, kuin mitä edellisessä väestöennusteessa osattiin odottaa (SVT, Väestöennuste 2015).

Syynä väestön vähenemiseen on syntyvyyden lasku. Jo nyt Suomessa kuolee vuosittain enemmän ihmisiä kuin syntyy (SVT, Väestöennuste 2019). Samanaikaisesti väestö ikääntyy. Yli 74-vuotiaiden määrän ennustetaan kasvavan nykyisestä 524000 henkilöstä 910443 henkilöön vuonna 2040. Väestöllinen huoltosuhde heikkenee kaikissa kunnissa. Kehitys vaikuttaa erityisesti väestöltään pieniin, alle 5000 asukkaan kuntiin, joissa väestökato on voimakkain ja huoltosuhde jo valmiiksi korkea. (SVT, Väestöennuste 2019) Suuntaus on sama kuin kansainvälisesti (Martinez-Fernandez 2016).

Alueelliseen väestökehitykseen vaikuttaa maan sisäinen muuttoliike. Väestö siirtyy pienistä taajamista suurempiin taajamiin, joissa kehitysedellytykset näyttävät paremmilta. (Nurmio ym. 2017) Muuttajat ovat enimmäkseen työikäisiä, jotka vaihtavat asuinpaikkaansa opiskelun tai työn takia. Tämä muuttoliike voimistaa taajamien välisiä eroa ja väestörakenteen vinoutumista supistuvilla alueilla. (Myrskylä, 2012)

Väestön väheneminen ja ikääntyminen ovat heikentäneet palvelutarjontaa ja palveluiden saavutettavuutta kasvualueiden ulkopuolelle jäävissä taajamissa. Ostos- ja asiointimatkat ovat maaseutumaisissa kunnissa yli puolet pidempiä kuin kaupunkimaisissa kunnissa (Liikenneministeriö 1999; Rehunen ym. 2012). Vuosien 1980-2010 välisenä aikana maaseudun joukkoliikenne on supistunut merkittävästi (Rönkkö 2010). Julkisia koulutus-, sosiaali- ja terveyspalveluita on jouduttu keskittämään ja pankkeja, posteja sekä erikoisliikkeitä sulkemaan. Syitä palveluverkon muutoksiin ovat julkisiin palveluihin kohdistuvat säästöt, kysynnän pieneneminen väestöään menettävissä kunnissa ja kuluttajien hakeutuminen laajojen valikoimien luokse. (Rehunen ym. 2012)

Kuntien asukasluvun väheneminen vaikuttaa taajamarakenteeseen Rakennuksia, erityisesti asuntoja, tyhjenee ja tästä seuraa ylitarjontaa, mikä laskee asuntojen hintaa (Beeck 2011; Martinez-Fernandez ym. 2012). Taloudellisen tilanteen kiristyessä kunnalla ei lopulta ole enää resursseja ylläpitää omaa rakennuskantaansa ja infrastruktuuriaan kunnossa (Ročak 2016). Kehityksellä on väistämättä myös vaikutus paikallisiin asukkaisiin, heidän hyvinvointiinsa ja elämänlaatuunsa (Visvizi ja Lytras 2018).

Suomessa väestöltään vähenevien kuntien taajamia on tarkasteltu yhdyskuntasuunnittelun kontekstissa (Mäntysalo 2006; Mönkkönen 2006, Aarrevaara 2015). Asukkaiden osallistumista oman asuin- ja elinympäristönsä kehittämiseen on puolestaan käsitelty laajasti aluekehittämiseen liittyvässä tutkimuksessa (Komulainen 1998; Mononen ym. 2013; Kopomaa ja Salin 2018). Pienten taajamien kehittämistoimet ja niitä tukevat kehittämisen ohjelmat, esimerkiksi Leader-toiminta, nostavat esille asukkaiden osallistamisen ja yhteissuunnittelun merkityksen. Yhdyskuntasuunnittelun perinteessä asukkaiden osallistuminen on kuitenkin nähty lähinnä mielipiteiden esittämisenä ilman omaa aktiivista osallistumista kehittämistyöhön (Staffans 2004). Tämän artikkelin pohjana olevan kyselytutkimuksen kautta pyritään laajentamaan tulokulmaa myös syihin, miksi omaehtoista kehittämistyötä asukkaiden keskuudessa ei juuri esiinny. 
Kuntien väestökadon jatkuessa tulevina vuosikymmeninä tarvitaan lisää tietoa siitä, miten nykyistä taajamarakennetta voidaan yhdyskunta- ja rakennussuunnittelun keinoin kehittää vastaamaan muuttuneita tarpeita. Tarvitaan kehitysehdotuksia, jotka keskittyvät taajaman eheyttämisen kannalta oleellisiin toimenpiteisiin. Toisaalta taajaman kehittämistä ei tulisi rajata liian tiukasti kuntarajojen sisäpuolelle, vaan tarkastelualueen tulisi ulottua myös kuntarajojen ulkopuolelle. Lisäksi tulisi arvioida, miten vapaa-ajan asumisen muuttuminen ympärivuotisemmaksi vaikuttaa väestöään menettävien kuntien palveluihin, tiloihin ja yhteisöön.

Alueiden supistumisen syyt ja seuraamukset ovat moniulotteisia. Eheän ja toimivan taajamarakenteen sekä elinympäristön laadun kehittämiseksi tarvitaan moninaista tietoa. Osallistamalla asukkaat mukaan suunnitteluprosessiin saadaan tietoa siitä, miten he suhtautuvat väestön vähenemiseen ja miten muutokset taajamassa ovat vaikuttaneet heidän elämäänsä. Tutkimuksen tarkoituksena on kuvata vakituisten ja vapaa-ajan asukkaiden näkemyksiä väestöltään supistuvien taajamien nykytilasta ja kehittämismahdollisuuksista. Tutkimuskysymykset ovat:

1) Mitä palveluita asukkaat pitävät tärkeinä omassa taajamassaan?

2) Mitä palveluita asukkaat käyttävät naapurikuntien taajamissa?

3) Mikä on parasta omassa kunnassa ja mitä asioita tulisi kehittää?

4) Miten asukkaat haluaisivat osallistua oman taajamansa kehittämiseen?

Tutkimus on toteutettu kolmen väestöltään vähenevän kunnan tapaustutkimuksena. Tutkimus on pohjatietoa tuottava osatutkimus. Se on osa laajempaa kokonaisuutta, jossa sovelletaan osallistavaa suunnittelua prosessina väestöltään supistuvien alueiden kehittämisessä.

\section{Teoreettinen tausta}

Kuntien tehtävänä suomalaisessa yhteiskunnassa on tuottaa palveluita, kehittää elinvoimaa, toteuttaa paikallista itsehallintoa ja luoda identiteettiä (Kuntalaki 2015). Supistuva kunta (engl. shrinking city, shrinking municipality, shrinking rural area) käsitteenä tarkoittaa aluetta, jossa väestö vähenee yhtäjaksoisesti useamman vuoden ajan, ja jossa väestön väheneminen vaikuttaa samalla myös alueen väestörakenteeseen ja talouteen (Wiechmann 2007; Hollander ym. 2009). Ei ole kuitenkaan olemassa yhtä tiettyä arkkityyppiä supistuvasta kunnasta, vaan jokainen kunta on sosiaalisten, kulttuuristen, poliittisten ja taloudellisten tekijöiden sekä historian muovaama uniikki kokonaisuus (Haase ym. 2017). Supistuvan kunnan sisällä väestökato ei aina jakaudu tasaisesti, vaan väestöltään pienenevän taajaman vieressä voi sijaita väestöltään kasvava taajama (Bontje ja Musterd 2012). Taajamalla tarkoitetaan Tilastokeskuksen määritelmän mukaan yhtenäistä rakennustihentymää, jossa on vähintään 200 asukasta.

Historia on osoittanut, että mitä tahansa kuntaa voi kohdata väestön menettäminen (Lampen ja Ozwar 2008; Grossmann ym. 2013). Teoksessa Atlas of Shrinking Cities Oswalt ja Rieniets (2006) määrittelevät kuntien supistumiselle kolme eri syytä: luonnonolosuhteista tai sodista johtuva tuho, raaka-aineiden tai työpaikkojen loppuminen sekä muuttoliike ja siitä johtuva väestörakenteellinen tai taloudellinen muutos. Euroopassa asukasluvun väheneminen tapahtuu usein maaseutualueilla nuorten muuttaessa pois suurempiin kaupunkeihin (Haase ym. 2012). Supistuville kunnille muodostuu monesti samankaltainen identiteetti (Lampen ja Ozwar 2008). Erityisesti kunnan koosta riippumattomat ongelmat, kuten palveluiden väheneminen ja asiointimatkojen pidentyminen, muistuttavat toisiaan (Rehunen 2012). Kaupungistuminen lisää kasvavien ja supistuvien 
kuntien välistä eroa (Hollander ym. 2009). Kuntien väestökato on moniulotteinen ilmiö, johon vaikuttavat sosiaaliset, taloudelliset, maantieteelliset ja tilalliset ulottuvuudet ja seuraukset (Martinez-Fernandez ym. 2012). Supistumista voidaan kuvata hallitsemattomaksi kehitykseksi, jossa kerran alkanut negatiivinen kierre voimistuu ja johtaa kumulatiiviseen prosessiin (Myrdal 1957; Tietjen ja Jørgensen 2016).

Yhdyskuntasuunnittelulla tarkoitetaan alueiden käytön ja rakentamisen järjestämistä niin, että se luo edellytykset hyvälle ja kestävälle elinympäristölle (Maankäyttö- ja rakennuslaki 1999). Maankäytön suunnittelulla ja kaavoituksella voidaan ohjata alueiden kasvukehitystä ja asettaa reunaehtoja tulevien asuin-, palvelu-, liike-, toimisto- ja teollisuusrakennusten sijoittumiselle. Supistuvien kuntien kehittämisen lähtökohdat ovat joiltain osin toisenlaiset kuin kasvualueiden. (Mäntysalo 2006; Herrmann ym. 2016) Supistuvien kuntien taajamarakenne muuttuu ylimitoitetuksi väestön, työpaikkojen ja palveluiden vähenemisen myötä. Rakennuksia ja tiloja tyhjenee. (Herrmann ym. 2016) Kuntien taloudellinen tilanne kiristyy verotulojen pienetessä asukkaiden ja yritysten poismuuton myötä. Ikääntyvän väestön määrä kasvaa ja lisää sosiaalija terveyspalveluiden tarvetta. Toisaalta muiden palveluiden, kuten päivähoito- ja koulutus, käyttäjämäärä vähenee. (Raatikainen 2004)

Kuntien virkamiesten reaktio supistumiskehitykseen vaihtelee. Osa virkamiehistä vähättelee tai vastustaa kehitystä, osa taas hyväksyy sen ja pyrkii kääntämään tilanteen voitoksi (Haase ym. 2012). Väestömäärän pieneneminen vaikuttaa taajaman rakennettuun ja koettuun ympäristöön, paikallisiin asukkaisiin ja alueen imagoon (Sulzer 2007). Väestön vähenemistä ei tule kuitenkaan tarkastella pelkästään ongelmana, vaan se avaa myös uusia mahdollisuuksia alueiden kehittämiselle ja yhteisöllisyyden vahvistamiselle (Hollander 2009). Supistuvat kunnat voivat hyötyä niistä ominaispiirteistä, joita niillä on jo valmiiksi enemmän verrattuna kasvaviin kaupunkialueisiin: asunnot ovat edullisia, vapaita toimitiloja löytyy, ei ole liikenneruuhkia ja luonto on lähellä (Bontje ja Musterd 2012). Maaseutuidylliä ja luontoa onkin pidetty syynä vastakkaiseen suuntaan tapahtuvalle muuttoliikkeelle (Hersund 2012). Vahva yhteisöllisyyden tunne, parempi elämänlaatu, luonnonläheisyys ja rikas kulttuurihistoria houkuttavat inmisiä muuttamaan maaseututaajamiin (McGranahan ym. 2011).

Monipaikkaisen asumisen käsite on yleistynyt viime vuosikymmeniä (Roca 2013; Müller 2014; Antikainen ym. 2017). Suomalaiset viettävät yhä enemmän aikaa kaupunkialueiden ulkopuolella sijaitsevalla vapaa-ajan asunnollaan. Kesämökin varustelutasoa on nostettu ja käyttö muuttunut ympärivuotisemmaksi (Pitkänen ja Vepsäläinen 2008). Suomessa on 509800 kesämökkiä ja yli puolet suomalaisista käyttää vapaa-ajan asuntoa vähintään satunnaisesti. JärviSuomen ja rannikkoseudun supistuvissa taajamissa asukasmäärä saattaakin nousta kesällä moninkertaiseksi, jos vapaa-ajan asukkaat otetaan huomioon. (SVT, Rakennukset ja kesämökit 2018)

Supistuvissa kunnissa toiminta tukeutuu vahvasti paikallisiin palveluihin. Hallinnon ja palveluiden järjestäminen on usein limittäisempää rajallisten resurssien takia. Väestöään menettävien kuntien on usein myös mahdollista toimia spontaanimmin ja kehittää toimintaansa ympäristössä tapahtuvien muutosten pohjalta. (Allen ym. 2016) Ympäristön muuttuessa paikallisen elinvoiman keskiössä on kyky uudistua, joustaa, tunnistaa tapahtuvat muutokset ja kehittää toimintaa muutosten pohjalta (Sallinen ym. 2011).

Taajaman eheyttäminen ja sopeuttaminen uuteen tilanteeseen on usein luontevampi vaihtoehto kuin pyrkiä takaisin kasvun polulle. Viisaan supistumisen lähtökohtana on tutkia, mitä taajama tarjoaa asukkailleen, mitkä asiat tekevät taajamasta ainutlaatuisen. (Popper ja Popper 2002) Keskeistä on myös tunnistaa todelliset resurssit ja mahdollisuudet eikä pohjata suunnitelmia toiveisiin tai 
epärealistisiin olettamuksiin. Supistuvien kuntien taajamien kehittämisen tavoitteena on turvata nykyisten asukkaiden hyvinvointi ja nykyisen rakennuskannan ja infrastruktuurin ylläpito ja sopeuttaminen sekä säilyttäminen. (Mönkkönen 2006) Laaja osallistuminen, avoimuus, yhteistyö, kokonaisvaltainen lähestymistapa sekä tulevaisuusorientaatio ovat kestävän suunnittelun tunnuspiirteitä (Meadowcroft 1999).

Pehmeät arvot, kuten arkiviihtyvyys ja asuinympäristöjen laatu, nousevat yhä vahvemmin esille supistuvien alueiden kehittämisessä (Karjalainen 2004). Asukkaiden väliset sosiaaliset verkostot ja yhteisöllisyys tukevat taajamien toimintaa muuttuvassa ympäristössä (Coleman 1988; Hyrkäs 2009; Haase ym. 2012; Koizumi 2016). Sosiaalinen pääoma ja osallisuus voidaankin nähdä väestöltään supistuvien alueiden voimavarana (Aldrich ja Meyer 2015).

Osallisuudesta on säädetty useissa laeissa, kuten hallintolaissa ja kuntalaissa. Maankäyttö- ja rakennuslaki (2000) velvoittaa kuntia kuulemaan asukkaita osana suunnitteluprosessia. Lain tavoitteena on turvata jokaisen osallistumismahdollisuus asioiden valmisteluun. Lisäksi lain tarkoituksena on varmistaa suunnittelun laatu, vuorovaikutteisuus, asiantuntemuksen monipuolisuus ja avoin tiedottaminen käsiteltävinä olevista asioista.

Osallisuus on käsitteenä vaikea, koska sitä käytetään monessa eri tilanteessa ja merkityksessä (Isola ym. 2017). Usein osallistumista (engl. participation) ja osallisuutta (engl. involvement) käytetään synonyymeina, vaikka ne sisällöllisesti poikkeavat toisistaan. Osallistuminen voi tarkoittaa kapeimmillaan vain mukana olemista (Nivala ja Ryynänen 2013). Osallisuus puolestaan syntyy osallistumisen, toiminnan ja vaikuttamisen kautta (Kettunen ja Kivinen, 2012). Osallistuminen voi siis olla tavoite ja toiminnan muoto, jolloin sillä pyritään edistämään osallisuutta. Osallisuuden kokemus on kuitenkin aina subjektiivinen, vahvasti tunneperäinen ja tilannesidonnainen.

Osallisuuden mahdollisuuksia on kuvattu eri mallien kautta, joista yleisimpiä ovat hierarkkiset mallit (esim. Arnstein 1969; Horelli 1994) ja ulottuvuusmallit (esim. Kohonen ja Tiala 2002; Sihvo ym. 2018). Tunnetuin näistä on Arnsteinin (1969) kehittämä tikapuumalli, jossa yksilön valta kasvaa tikapuun askelmia ylöspäin mentäessä. Alimmilla askelmilla (manipulaatio ja terapia) ei ilmene osallisuutta. Seuraavilla kolmella askelmalla (tiedonsaanti, konsultaatio, yhteissuunnittelu) yksilön mielipiteitä kuullaan, mutta hänellä ei ole päätösvaltaa. Kolmella ylimmällä portaalla (kumppanuus, delegoitu toimivalta ja kansalaisvalvonta) yksilöllä on päätös- ja toimintavaltaa. Hierarkkisia malleja on kritisoitu siitä, että ne keskittyvät kuvaamaan yksilön valtaa päätöksenteossa eivätkä huomioi osallisuutta vuorovaikutteisena prosessina (Nivala ja Ryynänen 2013). Esimerkiksi ministeriöiden ja Kuntaliiton yhteisesti toteuttamassa osallisuushankkeessa osallisuutta jäsennettiin ulottuvuuksina. Kuntalaisten osallisuus kunnallisessa päätöksenteossa ja palveluiden käytössä jaettiin neljään ulottuvuuteen: 1) tieto-osallisuus, 2) suunnitteluosallisuus, 3) päätösosallisuus ja 4) toimintaosallisuus (Kohonen ja Tiala 2002; myös Sihvo ym. 2018).

Asiantuntijakeskeisen suunnittelun rinnalla tarvitaan laajaa vuorovaikutukseen perustuvaa suunnittelua (Taylor 1998). Aluekehittämisessä on siirrytty viime aikoina kohti kommunikatiivisempia menetelmiä, kuten asukasfoorumeja, sähköisiä kyselyjä ja mobiilisovelluksia, joiden kautta mahdollistetaan väestön laajempi osallisuus (Bäcklund ym. 2002). Osallistava suunnittelu etenee syklisesti, tarkentuen asteittain (Victor ja Boynton 1998). Suunnittelu tapahtuu yksilö-, ryhmä- ja organisaatiotasolla. Monitoimijuus ja eri näkökulmat edistävät uuden tiedon muodostamista, kun myös toimijoiden hiljainen tieto saadaan näkyväksi (Nonaka ja Takeuchi 1995). Näin vuorovaikutteinen suunnitteluprosessi mahdollistaa uusien ratkaisujen syntymisen (Faludi 2000). 
Asukkaiden osallistamisen uskotaan tuottavan kestävämpiä ratkaisuja taajamien kehittämiseen, koska ne perustuvat asukkaiden paikalliseen tietoon (FosterFishman ym. 2007; Wagenaar 2007; Boonstra ja Boelens 2011). Osallistavan suunnittelun vahvuutena voidaankin pitää sitä, että asukkailla on välitön kokemus alueen ongelmista; he näkevät ongelmien kokonaisuuden, niiden väliset kytkennät ja ajallisen kehityskaaren (Wagenaar 2007). Staffansin (2004) mukaan paikallinen tieto on kulttuurista ymmärtämistä, joka on sidoksissa fyysisiin paikkoihin. Asukkaat hahmottavat taajaman toiminnallisena, sosiaalisena ja symbolisena tilana (Bäcklund 2002).

Kehittäjien tietopohja perustuu tekniseen ja prosessoituun tietoon, kun taas asukkaiden paikalliseen ja kokemukselliseen tietoon (Lund ja Juujärvi 2016; Wagernaar 2007). Asukkaiden osallistumismahdollisuuksia saatetaan kuitenkin rajoittaa ja heidän tekemiään kehittämisehdotuksia sivuuttaa, koska asukkaat eivät osaa asiantuntijakieltä. Heitä pidetään usein liian tavallisina, oman reviirinsä suojelijoina tai loputtomien toivelistojen esittäjinä (Staffans 2004; Häikiö 2007). Tärkeää on kuitenkin luoda avoimuuden ja luottamuksen ilmapiiri asukkaiden ja kehittäjien välille. Moniammatillinen kehittämistyö edistää sosiaalisesti kestävää innovointia. (Parjanen ym. 2016)

Osallistava suunnittelu kasvattaa yhteistyökykyä sekä tukee yksilöiden ja yhteisöjen kapasiteettia ratkaista muuttuvan asuinympäristönsä asettamia haasteita. Paikallistuntemus avaa hyvät mahdollisuudet löytää keinoja ongelmaratkaisujen löytymiseksi ja niiden toteuttamiseksi. Supistuvien kuntien kohdalla kyse voi olla jo olemassa olevien resurssien luovasta ja uudenlaisesta yhdistelystä. (Manzini 2015)

\section{Aineisto ja menetelmä}

Aineisto hankittiin kesällä 2019 kyselyllä kolmesta Elinvoimainen taajama hankkeeseen osallistuneesta kunnasta. Tavoitteena hankkeessa on kehittää menettelytapoja ja ratkaisuja väestöltään ja palveluiltaan supistuvien kuntien taajamien elinvoimaisuuden tukemiseen yhdyskunta- ja rakennussuunnittelun keinoin. Tässä artikkelissa käsiteltävään kyselytutkimukseen valitut kunnat ovat Harjavalta, Kurikka ja Pertunmaa, jotka poikkeavat toisistaan niin maantieteelliseltä sijainniltaan kuin myös väestömäärältään ja -rakenteeltaan.

\section{Taustatiedot kunnista}

Harjavalta on Satakunnan maakunnassa sijaitseva ja Porin seutukuntaan kuuluva 6942 asukkaan (SVT, Väestön ennakkotilasto 2019) kaupunki. Harjavaltaan on hyvät liikenneyhteydet niin henkilöautolla, junalla kuin myös linjaautolla. Harjavallan keskusta on kasvanut merkittävästi 1900-luvun alussa etenkin pienteollisuuden johdosta. Harjavaltaan rakennettiin 1920-luvulla keuhkotautiparantola Satalinna ja 1930-luvulla Kokemäenjoessa sijaitseva vesivoimalaitos. Harjavalta on tunnettu suurteollisuuspuistostaan, jossa toimii mm. kuparisulatto ja nikkelinjalostamo. Harjavallassa merkittävä virkistys- ja vapaaajan alue on Hiittenharjun urheilukeskus.

Kurikka on Etelä-Pohjanmaan maakunnassa sijaitseva ja Seinäjoen seutukuntaan kuuluva 20707 asukkaan (SVT, Väestön ennakkotilasto 2019) kaupunki. Kurikasta on tullut kuntaliitosten, Jurva vuonna 2009 ja Jalasjärvi vuonna 2016, seurauksena pinta-alaltaan maakunnan suurin ja väkiluvultaan toiseksi suurin kaupunki. Kurikka on yksi Suomen merkittävimmistä maatalouskunnista. Kurikkaan on hyvät yhteydet henkilöautolla ja kohtalaisen hyvät linjaautolla. Kurikassa on ollut rautatieasema, mutta henkilöliikenne rataosuudella Seinäjoki-Kaskinen lopetettiin 1960-luvulla. Noin 800 lukio- ja ammattikouluopiskelijalle suunnattu Kurikan Kampus avasi ovensa syksyllä 2018. 
Pertunmaa on Etelä-Savon maakunnassa sijaitseva ja Mikkelin seutukuntaan kuuluva 1698 asukkaan (SVT, Väestön ennakkotilasto 2019) kunta. Pertunmaan kaksi päätaajamaa ovat kirkonkylä ja Kuortti, jotka sijaitsevat noin kymmenen kilometrin etäisyydellä toisistaan. Kuortti on helposti saavutettavissa henkilöautolla ja linja-autolla. Kirkonkylään puolestaan ei ole julkista liikennettä. Kunnan julkiset palvelut sijoittuvat kirkonkylään, kun taas yritykset Kuorttiin. Kuortin ABChuoltoasema on myös suosittu pysähdyspaikka ohikulkijoille. Pertunmaalla on noin 1700 vapaa-ajan asuntoa, mikä moninkertaistaa kunnan väestömäärän kesäisin.

Yhteistä kaikille kolmelle kunnalle on väestön ikääntyminen ja väheneminen. Kehitys on kaikista voimakkain Kurikassa, jossa väestömäärän ennustetaan laskevan 23 prosenttia ja yli 74-vuotiaiden määrän kasvavan 49 prosenttia vuoteen 2040 mennessä (Kuvio 1.). Kunnat eroavat toisistaan taajama-asteen (Kuntien avainluvut 2018) ja väestötiheyden (Elinympäristön tietopalvelu Liiteri 2018) suhteen. Harjavalta on kompakti, väestötiheyden ollessa 57 as $/ \mathrm{km} 2$. Kurikan sisäiset etäisyydet ovat pisimmillään $100 \mathrm{~km}$. Pinta-alaltaan isossa kunnassa väestöntiheys on $12 \mathrm{as} / \mathrm{km} 2$. Pertunmaa on harvaan asuttu, jos tarkastellaan pelkästään vakituisia asuintaloja. Kunnan väestötiheys on 5 as $/ \mathrm{km} 2$.

Pitkät etäisyydet ja heikot julkisen liikenteen yhteydet vaikuttavat myös henkilöautojen määrään. Pertunmaalla henkilöautoja on eniten, Harjavallassa taas vähiten (Elinympäristön tietopalvelu Liiteri 2018). Asuinkunnassa työssäkäyvien osuus on kaikissa kolmessa kunnassa noin 58-68 \%. Tämä tarkoittaa, että merkittävä määrä työikäisiä käy töissä naapurikunnissa. Harjavallan työpaikkaomavaraisuus on $147 \%$, mikä tarkoittaa, että Harjavallassa käydään töissä, mutta asutaan muualla. (Kuntien avainluvut 2018)

Väestörakennetta tarkasteltaessa Kurikassa on suhteessa eniten alle 15vuotiaita (Kuntien avainluvut 2018). Pertunmaalla on puolestaan suhteessa eniten yli 74-vuotiaita (SVT, Väestön ennakkotilasto 2019). Väestörakenteen erot näkyvät myös ruokakuntien koossa. Kurikassa yhden henkilön (37\%), kahden henkilön (35\%) ja yli kahden henkilön (28\%) ruokakunnat jakautuvat tasaisemmin kuin Harjavallassa tai Pertunmaalla, joissa on eniten (vajaa $50 \%$ ) alle yhden henkilön ruokakuntia. (Kuntien avainluvut 2018)

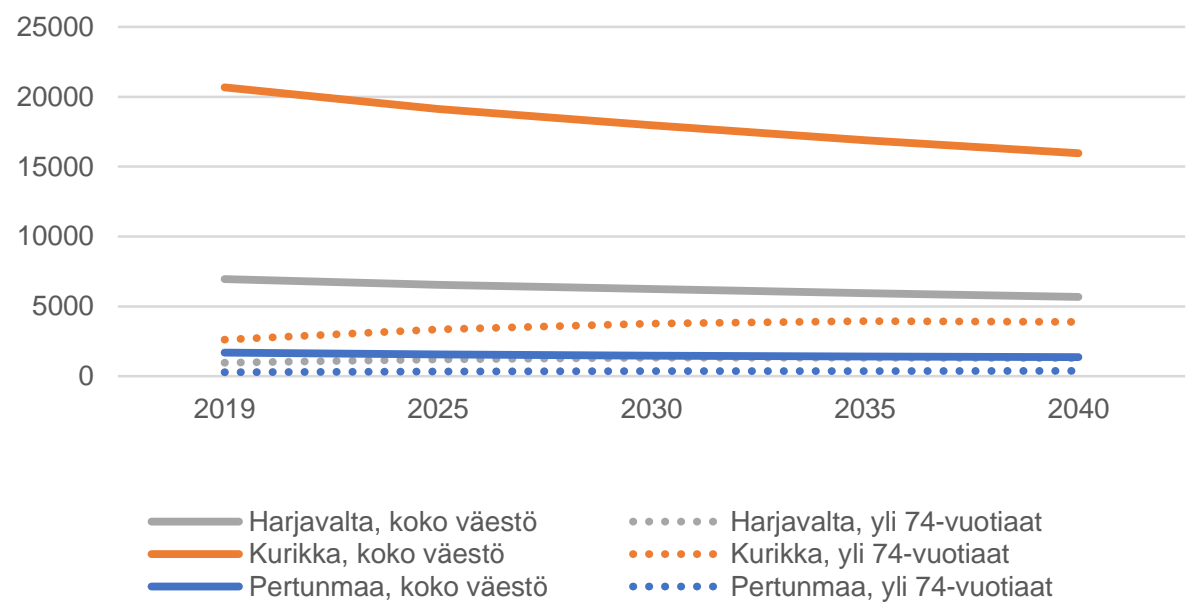

Kuvio 1. Alueellinen väestöennuste 2019-2040 (Tilastokeskus, 2019).

\section{Aineiston hankinta ja analyysi}

Kyselylomake laadittiin Elinvoimainen taajama -hankkeessa. Lomakkeen laatimisessa hyödynnettiin aikaisempien tutkimusten kyselylomakkeita (Strandell 1999; 2005; 2011; 2017). Kyselylomakkeen kehittämiseen osallistuivat Aalto- 
yliopiston Sotera tutkimusryhmän lisäksi Harjavaltaan, Kurikkaan ja Pertunmaalle maisterivaiheen lopputyötään tekevät arkkitehtiopiskelijat ja kyseisten kuntien kaupungin- ja kunnanjohtajat. Neljä kuntien edustajaa esitestasi kyselylomakkeen, jonka perusteella monivalintakysymyksiin lisättiin puuttuvia vaihtoehtoja. Kurikan kyselyyn yhdistettiin jokirannan kehittämistä koskevia kysymyksiä, jolloin kyselylomakkeen kokonaispituus piteni viidellä kysymyksellä.

Kyselylomake sisälsi monivalintakysymyksiä dikotomisin vastausvaihtoehdoin, likert-vastausasteikollisia ja avoimia kysymyksiä. Kysymykset koskivat vastaajien taustatietoja, palveluiden tärkeyttä ja käyttöä sekä taajamien kehittämistä. Lisäksi kysyttiin, mikä on asukkaiden mielestä nykyisin parasta kunnassa ja miten he haluaisivat vaikuttaa taajamansa kehittämiseen.

Kyselystä tiedotettiin paikallislehdessä, kunnan kotisivuilla ja sosiaalisessa mediassa. Kysely kohdistettiin kunnan vakituisille asukkaille ja Pertunmaan osalta myös vapaa-ajan asukkaille. Kyselyn toteutustapa vaihteli kunnittain. Sähköinen tiedonkeruu toteutettiin Webropol-palvelimen kautta. Lisäksi kyselyyn oli mahdollista vastata paperilomakkeella, joita jaettiin Harjavallan ja Kurikan kirjastoissa sekä Harjavallan Markkinoilla ja Kurikan Asu\&Elä-messuilla. Pertunmaalla paperilomakkeet lähetettiin kirjepostilla vakituisten ja vapaa-ajan asukkaiden koteihin (2174 kotitaloutta). Vastauksia saatiin yhteensä 1052, joista 110 oli Harjavallasta, 366 Kurikasta ja 576 Pertunmaalta. Määrällinen aineisto analysoitiin käyttäen Excel-taulukkolaskentaohjelmaa ja tulokset esitetään frekvenssi- ja prosenttijakaumina. Avointen kysymysten vastaukset on luokiteltu aineistolähtöisellä sisällön analyysillä (Tuomi ja Sarajärvi 2002).

\section{Tulokset}

\section{Kyselyyn vastanneiden taustatiedot}

Kyselyyn vastanneista suuri osa (84\%) oli asunut kunnassa yli 5 vuotta. Pääsääntöinen asuintalon talotyyppi oli omakotitalo. Vastanneista kunnan keskustassa asui Harjavallassa $27 \%$, Kurikassa $35 \%$ ja Pertunmaalla $42 \%$. Kurikan vastaajista $8 \%$ asui Jurvan taajamassa ja $19 \%$ Jalasjärven taajamassa. Pertunmaalla vapaa-ajan asukkaiden osuus vastanneista oli $61 \%$. Ruokakuntien koko jakautui Harjavallassa tasaisesti yhden, kahden ja yli kahden hengen ruokakuntiin. Kurikassa yli puolet vastaajista (53\%) asui yli kahden hengen ruokakunnassa, kun Pertunmaalla vastaava luku oli $17 \%$. Vastanneiden ikäjakauma painottui Pertunmaalla yli 54-vuotiaisiin, kun taas Kurikassa ja Harjavallassa vastanneiden ikäjakauma oli tasaisempi (Kuvio 2).

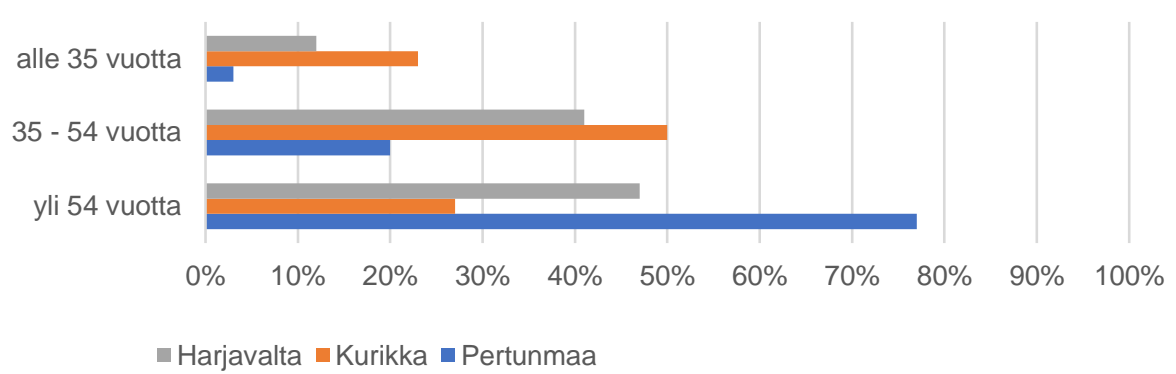

Kuvio 2. Vastaajien ikäjakauma kunnittain ( $\mathrm{N}=1052)$.

\section{Palvelut taajamassa}

Asukkaiden näkemykset omassa taajamassa olevista tärkeistä palveluista on esitetty kuviossa 3 . Vastaajista $89 \%$ piti taajaman tärkeimpinä palveluina päivittäistavarapalveluita. Sosiaali- ja terveyspalveluja pidettiin lähes yhtä tärkeinä $(80 \%)$. Perusopetus, päivähoito ja varhaiskasvatus nousivat esille kaikissa kolmessa kunnassa, mutta erityisesti Kurikassa korostui lapsiin ja nuoriin 
sekä koulutukseen liittyvien palveluiden merkitys. Vastaajista $63 \%$ piti tärkeinä myös vapaa-aikaan liittyviä liikunta- ja virkistyspalveluja sekä kulttuuripalveluja. Kurikassa elinkeinopalvelut oli mainittu muita kuntia useammin. Vähemmän tärkeinä palveluina taajamassa pidettiin erikoisliikkeitä ja seurakunnan tarjoamia palveluita. Valikosta puuttuvina muina palveluina mainittiin Kurikan osalta ravintolapalvelut ja tapahtumat. Pertunmaalla vastaavasti nostettiin esille tori, tapahtumat sekä pankki- ja jätehuoltopalvelut.

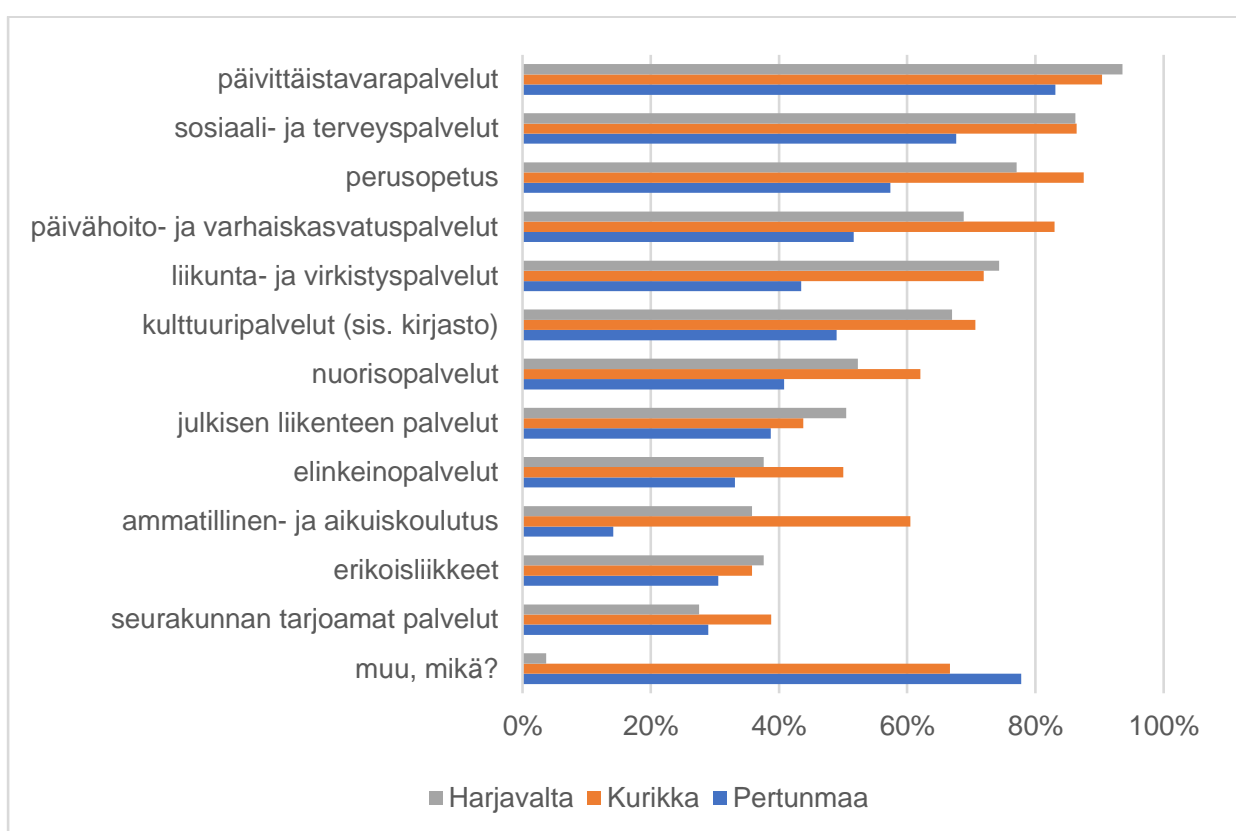

Kuvio 3. Vastaajien tärkeinä pitämät palvelut taajaman keskustassa ( $n=1034)$.

\section{Palvelut naapurikunnissa}

Asukkaiden käyttämät naapurikuntien palvelut sijoittuivat $12-58 \mathrm{~km}$ säteelle oman kunnan keskustasta. Harjavallassa asuvat $(n=79)$ asioivat eniten Porissa, joka sijaitsee noin $30 \mathrm{~km}$ etäisyydellä Harjavallasta. Vähemmän asioitiin Kokemäellä ja Nakkilassa, vaikka etäisyys on molempiin puolta lyhyempi kuin Poriin.

Porin palveluista eniten käytettiin erikoisliikkeitä sekä terveydenhuolto-, päivittäistavara-, kulttuuri- ja ravintolapalveluita. Erikoisliikkeet olivat vaate-, urheilu-, kenkä-, rauta- ja lemmikkieläinkauppoja. Kulttuuripalveluista mainittiin elokuvateatteri, kirjasto ja konsertit. Kokemäellä ja Nakkilassa asioitiin erikoisliikkeiden, kirpputorien, liikuntapalveluiden, päivittäistavarapalveluiden ja ravintolapalveluiden takia. Asiointitiheys Harjavallan ulkopuolella sijaitsevissa palveluissa oli keskimäärin joitakin kertoja kuukaudessa.

Kurikassa asuvat $(n=269)$ asioivat eniten Seinäjoella, joka sijaitsee noin $34 \mathrm{~km}$ etäisyydellä Kurikan keskustasta. Toiseksi eniten kurikkalaiset käyttivät Kauhajoen ja kolmanneksi eniten IImajoen palveluita. Väkiluvultaan Seinäjoki on näistä kolmesta kunnasta suurin (63 610 as), kun taas Kauhajoki (13 250 as) ja IImajoki (12 240 as) eivät eroa väkiluvultaan kovinkaan paljon toisistaan (SVT, Väestön ennakkotilasto 2019). Kauhajoki sijaitsee kuitenkin vastakkaisessa suunnassa kuin Seinäjoki, ja on näin ehkä vetovoimaisempi kuin Ilmajoki, joka sijaitsee Kurikan ja Seinäjoen välissä.

Kurikkalaiset käyttivät naapurikuntien liikunta- ja vapaa-ajan palveluita, kuten uinti, jalkapallo ja tanssi, lähes viikoittain. Päivittäistavarapalveluita, erikoisliikkeitä, ravintolapalveluita ja kulttuuripalveluita käytettiin kerran tai useammin kuukaudessa. Vielä harvemmin käytettyjä palveluita olivat erikoissairaanhoito, poliisi, verotoimisto, pankki, autohuolto, teatteri, ooppera ja Hoplop. Seinäjoen 
merkitys korostui myös rautatieaseman osalta, joka mahdollistaa liikkumisen laajemmin.

Pertunmaan osalta $(n=199)$ naapurikunnista suosituimpia olivat Heinola ja Mäntyharju. Kolmannella sijalla oli Mikkeli, jonne on matkaa 58 km. Mäntyharjussa ja Heinolassa käytettiin päivittäistavarapalveluita, terveyspalveluita, erikoisliikkeitä sekä kulttuuri- ja vapaa-ajanpalveluita, joita on Pertunmaan kirkonkylässä vain rajallisesti. Mikkelissä asioitiin edellä mainittujen palveluiden lisäksi erikoissairaanhoidon ja ravintolapalveluiden takia. Pertunmaalla asuvat käyttivät naapurikuntien palveluita viikoittain tai useita kertoja kuukaudessa.

Pertunmaan vapaa-ajan asukkaiden vastauksissa korostui sen naapurikunnan merkitys, joka oli mökkimatkan varrella. Palveluista yleisimpiä olivat päivittäistavarat ja erikoisliikkeet, jotka liittyivät rakentamiseen tai sisustamiseen. Vapaa-ajan asukkaille tärkeitä olivat myös erilaiset kulttuuripalvelut, kuten kesäteatterit, konsertit, taidenäyttelyt ja lavatanssit. Palveluiden käyttö painottui vapaa-ajan asukkailla pääsääntöisesti kesäkuukausille.

\section{Parasta omassa kunnassa}

Asukkailta kysyttiin myös, mikä on parasta heidän kunnassaan (taulukko 1). Kaikissa vastauksissa korostui luonto ja luonnon merkitys. Tämän lisäksi palveluiden merkitys nousi sekä Harjavallassa että Kurikassa esille: "sopivan kokoinen, kaikki tarvittavat palvelut lähellä, eskarista lukioon polku omalla paikkakunnalla" (Harjavalta). Monipuoliset liikunta- ja harrastusmadollisuudet olivat erikseen lueteltu Harjavallan tärkeimpinä ominaisuuksina. Pertunmaan ja Kurikan asukkaat korostivat asuinympäristön hyvinä puolina sitä, että "on tilaa, ei ruuhkia, lyhyet välimatkat - rauhallista ja turvallista" (Kurikka). Yhteisöllisyyden merkitys näkyi erityisesti Pertunmaan kohdalla, jossa "ihmiset ovat luotettavia ja tuttuja". Pertunmaan vapaa-ajan asukkaille "oma mökki järven rannalla, puhtaassa luonnossa" oli tärkeä.

Taulukko 1. Vastaajien parhaiksi esittämät asiat kunnassaan $(n=840)$.

\begin{tabular}{|c|c|c|c|}
\hline Harjavalta & Kurikka & $\begin{array}{c}\text { Pertunmaa } \\
\text { (vakituinen as.) }\end{array}$ & $\begin{array}{c}\text { Pertunmaa } \\
\text { (vapaa-ajan as.) }\end{array}$ \\
\hline $\begin{array}{l}\text { 1. luonto } \\
\text { 2. palvelut } \\
\text { 3. liikunta } \\
\text { 4. joki } \\
\text { 5. harrastukset }\end{array}$ & $\begin{array}{l}\text { 1. palvelut } \\
\text { 2. luonto } \\
\text { 3. rauhallisuus } \\
\text { 4. turvallisuus } \\
\text { 5. ihmiset }\end{array}$ & $\begin{array}{l}\text { 1. luonto } \\
\text { 2. rauhallisuus } \\
\text { 3. inmiset } \\
\text { 4. turvallisuus } \\
\text { 5. yhteisöllisyys }\end{array}$ & $\begin{array}{l}\text { 1. luonto } \\
\text { 2. rauhallisuus } \\
\text { 3. ihmiset } \\
\text { 4. mökki } \\
\text { 5. järvet }\end{array}$ \\
\hline
\end{tabular}

\section{Kehittämiskohteet}

Kun asukkailta kysyttiin, mitä asioita kunnassa tulisi kehittää viihtyvyyden parantamiseksi, olivat vastaajien kokemukset asuinkuntansa viihtyvyydestä erilaisia (taulukko 2). Harjavallassa $(n=67)$ asukkaat nostivat esiin, että taajaman ulkoalueita tulisi pitää huollettuina ja siisteinä ja tyhjiä rakennuksia tulisi korjata tai purkaa. Asukkaat toivoivat myös, että poliisi näkyisi enemmän katukuvassa. Julkista liikennettä tulisi kehittää lisäämällä ilta- ja viikonloppuvuoroja ja säilyttämällä linja-autoreitit joen pohjoispuolella. Joki koettiin tärkeänä elementtinä, joka "pitäisi saada näkyväksi ja käyttöön jotenkin. Jokiristeilyt, veneja kajakki/sup-vuokraus, kahvila rantaan, tanssilava ja jokitanssit". Joen pohjoispuolelle voisi sijoittaa päivittäistavarakaupan ja keskustaan lisää erikoisliikkeitä. Myös toritoimintaa voisi kehittää: "iltatori näin kesäaikaan olisi kiva, myös työssäkävijät pääsisivät torille ja ehkä keskustassa liikkuisi joku klo 18 jälkeen".

Kurikassa vastaajista $82(n=269)$ koki Kurikan keskustan kohtalaisen viihtyisänä paikkana, kun taas $65(n=269)$ kommentoi, ettei keskusta ole kovin viihtyisä. 
Yleisesti asukkaat näkivät, että keskustaa voisi kehittää lisäämällä puita ja istutuksia sekä kohdevalaisemalla tärkeitä rakennuksia talvella. Myös patsaita ja taidetta toivottiin enemmän keskustaan. Asukkaat kommentoivat myös vuonna 2014 puretun kaupungintalon tonttia, jota "voisi myös hyödyntää paremmin, koska tällä hetkellä se tuntuu hiukan keskeneräiseltä, ja tunnelma on pitkään ollut odottava sen suhteen, tuleeko siihen mitään tilalle". Keskustaan ehdotettiin uusia rakennusprojekteja ja vanhojen rakennusten kunnostamista. Lisäksi toivottiin lisää liikkeitä ja kahviloita keskustaan. Liikennejärjestelyt, uusi kiertoliittymä ja jatkuvat tietyöt saivat kritiikkiä. Jalasjärvellä ja Jurvassa asuvat kritisoivat sitä, ettei näitä taajamia "ole kehitetty yhtään mitenkään, puistot yms. löytyvät Kurikan keskustasta".

Pertunmaan vakituiset ja vapaa-ajan asukkaat $(n=318)$ toivat esille, että heidän kirkonkylänsä tyhjiin rakennuksiin tulisi saada toimintaa. Tärkeänä pidettiin myös vesistöjen puhtaanapitoa ja kunnostamista. Lisäksi toivottiin jätteiden lajittelun parantamista, keräyspisteiden lisäämistä ja selviä merkintöjä jäteastioihin. Vapaa-ajan asukkaille tärkeää oli lisäksi puhelin-, netti- ja sähköyhteyksien toimivuus ja teiden kunnostaminen. Julkista liikennettä sekä pyörätietä toivottiin Kuortin ja kirkonkylän päätaajamien välille. Palveluiden osalta vastaajat pitivät tärkeänä, että nykyiset palvelut säilyvät ja niiden aukioloaikoja pidennettäisiin iltaisin ja viikonloppuisin. Myös paikallistarjontaa ehdotettiin kehitettävän: "tuottajien tori voisi olla kesäviikonloppuisin, voisi ostaa tuotteita suoraan tuottajilta". Vastaajat toivat esille, että yhteistyötä naapurikuntien kanssa voisi kehittää samoin kuin myös Pertunmaan sisällä vakituisten ja vapaa-ajan asukkaiden välistä yhteisöllisyyttä. Kokonaisuudessaan vastaajista moni koki viihtyvänsä jo nyt hyvin Pertunmaalla.

Taulukko 2. Vastaajien keskeiset ehdotukset viihtyvyyden parantamiseksi ryhmitelty viiden eri aihepiirin mukaan ( $n=709)$.

\begin{tabular}{|c|c|c|c|}
\hline Aihepiirit & Harjavalta & Kurikka & Pertunmaa \\
\hline $\begin{array}{l}\text { 1. RAKENNUKSET } \\
\text { 2. ULKOTILAT } \\
\text { 3. LIIKENNE } \\
\text { 4. PALVELUT } \\
\text { 5. SOSIAALISUUS }\end{array}$ & $\begin{array}{l}\text { 1. tyhjien tilojen korjaus } \\
\text { 2. ulkotilojen siisteys } \\
\text { 3. lisää vuoroja } \\
\text { 4. lisää tapahtumia } \\
\text { 5. turvallisuus }\end{array}$ & $\begin{array}{l}\text { 1. keskustan eheytys } \\
\text { 2. kauniita istutuksia } \\
\text { 3. liikennejärjestelyt } \\
\text { 4. lisää erikoisliikkeitä } \\
\text { 5. Jurva ja Jalasjärvi }\end{array}$ & $\begin{array}{l}\text { 1. tyhjiin tiloihin toimintaa } \\
\text { 2. ulkovesistöjen kunto } \\
\text { 3. julkinen liikenne } \\
\text { 4. palveluiden säilyminen } \\
\text { 5. yhteistyö }\end{array}$ \\
\hline
\end{tabular}

\section{Osallistuminen}

Harjavallan ja Pertunmaan kyselyssä kysyttiin lopuksi, miten asukkaat haluaisivat vaikuttaa oman taajamansa kehittämiseen. Harjavallassa $74 \%$ vastaajista $(n=54)$ ilmoitti jo osallistuvansa tai haluavansa osallistua taajaman kehittämiseen. Vastanneet mainitsivat mahdollisina osallistumismuotoina kyselyihin vastaamisen, asukasiltoihin ja työpajoihin osallistumisen sekä luottamusmies-, vapaaehtois- ja yhdistystoiminnan. Lisäksi he ehdottivat voivansa olla mukana siivoustalkoissa, vanhustenhuollon asioissa tai lasten toiminnassa, kun "omatkin lapset ovat pieniä". Vastaajat toivat esille, että asukkaille voisi esimerkiksi myös järjestää vaikutusfoorumikeskustelun päättäjien kanssa. Vastaajista $9 \%(n=54)$ toi esille, ettei halua osallistua tai ettei osallistumismahdollisuuksia ole: "poliittiset päättäjät kuuntelevat, mutta eivät saa kuntalaisten toiveita toteutetuksi".

Pertunmaan kyselyssä vakituisista asukkaista $(n=108)$ noin kolmasosa koki, ettei halua osallistua tai pysty osallistumaan päätaajamien kehittämiseen. Usein syynä oli korkea ikä: "osallistukaa ja vaikuttakaa nuoremmat, minä osallistuin aikanani". Toisinaan syynä oli turhautuminen: "olen huomannut, ettei osallistuminen vaikuttaisi mitään. Kunnan luottamushenkilöt luovuttaneet päätösvallan pois, esim. seurakunta ja Essote". Kuitenkin kaksi kolmasosaa vakituisista asukkaista näki, että vaikuttaminen on mahdollista esimerkiksi vapaaehtoistyön kautta tai käyttämällä paikallisia palveluita. He olisivat valmiit 
osallistumaan myös yhteisiin talkoisiin, torin kehittämiseen, liikunta- ja kulttuuritapahtumien järjestämäiseen tai lasten ja nuorten kerhotoiminnan vetämiseen.

Pertunmaan vapaa-ajan asukkaista $(n=119)$ vajaa puolet totesi, ettei ole kiinnostunut osallistumaan päätaajamien kehittämiseen tai ei osaa ottaa kantaa asiaan. Usein syynä oli, että: "mökkiläisenä mahdollisuudet ovat rajallisia". Toisaalta ne vapaa-ajan asukkaat, jotka olivat kiinnostuneita osallistumisesta, toivat esille, että kesäasukkaita voisi ottaa enemmän mukaan kunnan toimintaan. Heillä voisi olla esimerkiksi "jonkinlainen rooli kunnanvaltuustossa". Vapaa-ajan asukkaat kokivat, että kyselyt, asukas/mökkiläisillat, talkoot ja muut tilaisuudet ovat sopiva tapa vaikuttaa. He myös korostivat viestinnän merkitystä: "kesäasukkaana seuraan mieluusti kunnan tilaa ja tapahtumia. Niihin liittyvä viestintä palvelisi puolin ja toisin".

\section{Pohdinta}

Supistuvien kuntien taajamien kehittämisessä keskeiseksi muodostuu toimivan, asukkaiden tarpeita palvelevan ja viihtyisän keskusta-alueen luominen. Väestön väheneminen vaikuttaa taajamarakenteeseen. Aarrevaara ja Rönkkö (2015) kuvailevat suomalaisten maaseututaajamien nykytilaa keskeneräiseksi. Taajamarakenne on hajanainen ja jäsentymätön. Tilat ja alueet ovat toiminnallisesti vajaakäyttöisiä. Kyselytutkimuksen vastauksissa taajamien keskeisiksi kehittämistoimiksi nousivat rakennuksiin, ulkotiloihin, liikenteeseen, palveluihin ja sosiaaliseen pääomaan liittyvät ehdotukset. Vastaukset osoittivat, että taajamien kehittämiseen liittyy myös Karjalaisen (2004) mainitsemia niin sanottuja pehmeitä tekijöitä, kuten arkiviihtyvyyden ja yhteisöllisyyden edistäminen.

Ulko- ja sisätilojen laatu vaikuttavat taajamien viihtyvyyteen ja imagoon. Kyselyyn vastanneista moni piti tärkeänä, että huonokuntoisia rakennuksia korjataan tai puretaan ja keskustaa mahdollisesti täydennysrakennetaan. Tyhjiin tiloihin ehdotettiin uusia toimintoja, jotka täydentäisivät taajaman palvelutarjontaa tai lisäisivät vapaa-ajan aktiviteetteja. Myös puistomaisten viheralueiden ja siistien, huollettujen ulkotilojen merkitys näkyi vastauksissa. Taajaman tärkeinä ominaispiirteinä pidettiin pienmittakaavaisuutta, luonnonläheisyyttä ja turvallista asuin- ja elinympäristöä. Taajamasta ei haluttu liian urbaania. Väestöltään vähenevien kuntien yhtenä vetovoimatekijänä onkin pidetty juuri maaseutuidylliä, joka tukee suurista kasvukeskuksista pienempiin taajamiin tapahtuvaa muuttoliikettä (Hersund 2012; McGranahan ym. 2011).

Väestöltään pienenevissä taajamissa pitkät ostos-, harrastus- ja asiointimatkat rytmittävät asukkaiden arkea. Kyselytutkimuksen tulokset osoittivat, että julkisen liikenteen heikentyminen on vahvistanut yksityisautoilua. Tämä tuo ne asukaat, joilla ei ole omaa autoa tai joilla on perheessä vain yksi auto, eriarvoiseen asemaan. Erityisesti julkisen liikenteen heikentyminen vaikuttaa ikääntyneiden arkeen, jos palvelut eivät sijaitse lähellä. Kestävillä liikkumismuodoilla, kuten kimppakyydit tai yhteiskäyttöautot, voitaisiin palveluiden saavutettavuutta parantaa. Taajamien välinen yhteistyö palveluiden järjestämisessä mahdollistaisi kattavamman palvelutarjonnan. Kaikkia palveluita ei voi eikä kannata järjestää yksin. Myös Meadowcroft (1999) tuo esille yhteistyön, kokonaisvaltaisen lähestymistavan sekä tulevaisuusorientaation merkityksen kestävien ratkaisujen kehittämisessä.

Yhteisöllisyys ja sosiaaliset verkostot vahvistavat taajaman muutoskestävyyttä (Coleman 1988; Hyrkäs 2009; Haase ym. 2012; Koizumi 2016). Taajaman keskustan kohtaamispaikat mahdollistavat sosiaalisen kanssakäymisen. Kyselytutkimuksessa kävi ilmi, että tori oli kaikkien kolmen kunnan asukkaille tärkeä paikka, ja toritoimintaa toivottiin kehitettävän pidempien aukioloaikojen mutta myös paikallisen tarjonnan suhteen. Tori onkin ollut perinteisesti taajaman 
keskeinen kohtaamispaikka (Agboola ym. 2018). Tori houkuttelee paikalle niin vakituisia kuin myös vapaa-ajan asukkaita sekä satunnaisia ohikulkijoita.

Vapaa-ajan asukkaat ovat voimavara, jota väestöltään vähenevien kuntien kehittämisessä voisi hyödyntää vahvemmin. Monipaikkaisuus ilmiönä on yleistymässä (Roca 2013; Müller 2014; Antikainen ym. 2017). Ihmiset viettävät yhä enemmän aikaa kaupunkialueiden ulkopuolella sijaitsevalla vapaa-ajan asunnollaan. Uudet vapaa-ajan asunnot ovat usein suunniteltu jo lähtökohdiltaan ympärivuotiseen käyttöön. Vapaa-ajan asukkaille suunnatut palvelut ovat perinteisesti mitoitettu kausiluonteisesti. Monipaikkaisuus saattaa kuitenkin nostaa tarvetta laajentaa palvelutarjontaa ja monipuolistaa tilojen käyttöä. Kyselytutkimukseen vastanneet vapaa-ajan asukkaat toivoivat esimerkiksi toritoiminnan jatkamista kesän jälkeenkin. Monipaikkainen asuminen edellyttää myös toimivia tietoliikenneyhteyksiä, toimintavarmoja sähköverkkoja sekä jätehuoltoa (Admiak ym. 2015).

Vapaa-ajan asukkailla on kiinteistön omistuksen myötä muodostunut tietynlainen paikkaan solmittu pitkäaikainen side. He myös maksavat kiinteistöveroa mökkikuntaan ja ovat näin merkittävä tekijä kunnan elinkeinoelämälle. Kyselytutkimuksessa nousivat esille kuitenkin myös monipaikkaisuuteen liittyvät haasteet. Vapaa-ajan asukkaat pitivät tärkeinä, että heidät huomioitaisiin paremmin palveluiden järjestämisessä ja infrastruktuurin ylläpidossa. Esimerkiksi mökkiteiden tai vesistöjen huono kunto sai kritiikkiä vapaa-ajan asukkailta. Julkisia palveluita, kuten terveydenhuollon palveluita, toivottiin laajennettavan myös vapaa-ajan asukkaiden käyttöön. Vapaa-ajan asukkaat ehdottivat myös, että heillä voisi olla rooli kunnan päätöksenteossa. Monipaikkaisuuden haasteet tuovat esille, että vapaa-ajan asukkaat mieltävät yhä useammin mökkikuntansa toisena kotikuntanaan (Valtiovarainministeriö 2018). Vapaa-ajan asukkaiden tuomat hyödyt ovat kunnan elinvoimaisuuden kannalta keskeisiä, ja näitä hyötyjä tulisi vahvistaa tukemalla yhteisöllisyyttä ja yhteenkuuluvuuden tunnetta.

Kyselytutkimuksella tavoitetaan usein vain tietty osa väestöstä. Vastaajia ovat monesti henkilöt, jotka ovat jo muutenkin aktiivisia tai joilla on huonoja kokemuksia. Tässä tutkimuksessa tavoitettiin hyvin yli 34-vuotiaat ikäluokat, 87 \% vastanneista, mutta lapset, nuoret ja nuoret aikuiset jäivät vähemmistöön. Erityisesti nuorten ja nuorten aikuisten ikäryhmien huomioiminen taajaman kehittämisessä olisi tärkeää. Merkittävä osa taajamien muuttoliikkeestä tapahtuu, kun nuoret lähtevät opiskelemaan tai töihin suurempiin taajamiin (Palttila 2002). Viihtyisä ja toimiva asuinympäristö sekä yhteisöllisyys vahvistavat suhdetta taajamaan. Nämä ovat myös tekijöitä, jotka saattavat houkuttaa nuoria palaamaan opiskelun jälkeen kotitaajamaansa.

Kyselytutkimuksesta käy ilmi, että osallistuminen ja myös halu osallistua on yksilöllistä. Moni vastanneista koki, että osallistuu jo yhdistys-, luottamus- tai vapaaehtoistoiminnan kautta taajaman kehittämiseen. Toiset pitivät kyselyä luontevana tapana osallistua ja vaikuttaa. Jotkut asukkaat ehdottivat, että he voisivat osallistua taajaman kehittämiseen konkreettisesti esimerkiksi talkootöiden kautta. Asukkaat, jotka eivät halunneet osallistua taajaman kehittämiseen, vetosivat korkeaan ikäänsä tai siihen, ettei osallistumisella kuitenkaan pysty vaikuttamaan kunnan virkamiesten päätöksiin. Vapaa-ajan asukkaista useat olivat valmiita osallistumaan taajaman kehittämiseen, mikäli kunta tarjoisi siihen mahdollisuuden.

Vastauksista käy ilmi, että asukkaiden osallistuminen jää usein Arnsteinin tikapuun alimmille portaille. Varsinaiseen yhteissuunnitteluun päästään harvoin, vaikka tahtotila olisikin asukkaiden puolesta olemassa. Ministereiden ja Kuntaliiton ulottuvuusmallin mukaisessa jaossa asukkaiden päätösosallisuus ja toimintaosallisuus jäävät usein toteutumatta. Asukkaat nähdään monesti pelkästään oman etunsa puolustajina suunnitteluprosessissa, vaikka juuri heidän 
kauttaan suunnitteluun saataisiin puuttuvaa paikallista niin sanottua hiljaista tietoa (Staffans 2004; Häikiö 2007). Asukkaille on muodostunut tunneperäistä kokemustietoa alueen vahvuuksista, arvoista ja ominaispiirteitä, mutta myös ongelmista, niiden kytköksistä ja kehityksestä ajallisesti. Asukkaat ovat kokeneet väestön vähenemisen seuraamukset ja sen vaikutukset arjen rutiineihin.

Aidon osallistumisen puuttuminen herättää myös epäluuloja ja turhautuneisuutta asukkaissa ja saattaa johtaa siihen, ettei asukkailla ole halukkuutta osallistua taajamansa kehittämiseen. Supistuvien kuntien taajamien kehittäminen niukoilla resursseilla on uudenlainen tehtävä niin suunnittelijoille kuin myös kunnan virkamiehille ja päättäjille. Kestävien ja toimivien ratkaisujen löytämiseksi tarvitaan monialaista osaamista ja vuorovaikutteista suunnitteluprosessia, jossa korostuvat avoimuus, luottamus, yhteistyö ja kokonaisvaltainen lähestymistapa. Asukkaat ja heidän aktiivinen osallistumisensa kehittämistyöhön ja omaehtoinen työnsä elinympäristön kehittämisessä tulisi nähdä resurssina, joka lisää taajaman elinvoimaa ja yhteisöllisyyttä.

\section{Johtopäätökset}

Yhteissuunnittelu avaa uusia mahdollisuuksia taajamien kehittämiseen, tilojen monipuolisempaan käyttöön ja taajamarakenteen eheyttämiseen. Kehittämistyön ei tulisi olla liikaa ylhäältä ohjattua, vaan tulisi tukea omaehtoista ja itseorganisoituvaa toimintaa antaen tilaa luoville ideoille ja näiden toteutukselle. Näin asukkaat omalla toiminnallaan voisivat vaikuttaa vahvemmin paikallisen identiteetin ja hyvän ympäristön kehittämiseen.

Monipaikkainen asuminen on sekä haaste että mahdollisuus. Vapaa-ajan asukkaat ovat tärkeitä kunnan elinkeinoelämän kannalta, mutta lisäävät myös palveluiden ja infrastruktuurin järjestämisen kustannuksia. Ehdotus kaksoiskuntalaisuudesta on ollut esillä viime aikoina. Kaksoiskuntalaisuus voisi mahdollistaa verotulojen tasaisemman jakautumisen kuntien kesken. Monipaikkaisuus ei kuitenkaan näy vielä kuntalaissa, vaikka inmisten arjesta on muodostunut entistä monipaikkaisempaa. Mökkikunnasta on tullut monelle vapaa-ajan asukkaalle jo ikään kuin toinen kotikunta. Monipaikkaisuuden tukeminen ja vapaa-ajan asukkaiden osallisuus- ja vaikutusmahdollisuuksien lisääminen hyödyntäisi kaikkia osapuolia ja tukisi vakituisten ja vapaa-ajan asukkaiden välistä yhteisöllisyyttä ja sosiaalista pääomaa.

\section{Kirjallisuus}

Aarrevaara, E. (toim.) 2015. Suomalainen maaseututaajama muutospaineessa - Suomalainen maaseututaajama 2010-luvulla -tutkimushankkeen loppuraportti. Lahden ammattikorkeakoulu. $164 \mathrm{~s}$. Lahden ammattikorkeakoulu Oy:n julkaisusarja, osa 3. ISBN 978-951-827-225-3.

Aarrevaara, E. \& Rönkkö, E. 2015. "Maaseututaajamien rakennettu ympäristö aluehistorian ja kulttuuriperinnön näkökulmista", Maaseudun uusi aika, vol. 3:2015. S. 5-19.

Adamiak, C.; Vepsäläinen, M.; Strandell, A.; Hiltunen, M.; Pitkänen, K.; Hall, M.; Rinne, J.; Hannonen, O.; Paloniemi, R. \& Åkerlund, U. 2015. Vapaa-ajan asuminen Suomessa - Asukas- ja kuntakyselyn tuloksia vapaa-ajan asumisen nykytilasta ja kehittämistarpeista. Suomen ympäristökeskus. $96 \mathrm{~s}$. Suomen ympäristökeskuksen raportteja 22:2015. ISBN 978-952-11-4500-1.

Agboola, O. P.; Rasidi, M. H.; Said, I. B.; Zakka, S. D. \& Shuaibu, A.-W. 2018. "Residents' Social Interactions in Market Square and Its Impact on Community Well-Being", Journal of Contemporary Urban Affairs, vol. 2:2. S. 24-32. 
Aldrich, D. \& Meyer, M. 2015. "Social Capital and Community Resilience", American Behavioral Scientist, vol. 59, S. 254-269.

Allen, C. R.; Birge, H. E.; Bartelt-Hunt, S.; Bevans, R. A.; Burnett, J. L.; Cosens, B. A.; Cai, X.; Garmestani, A. S.; Linkov, I.; Scott, E. A.; Solomon, M. D. \& Uden, D. R. 2016. "Avoiding Decline: Fostering Resilience and Sustainability in Midsize Cities", Sustainability, vol. 8:9.

Arnstein, S. R. 1969. "A ladder of citizen participation", Journal of the American Institute of planners, vol. 35:4, S. 216-224.

Beeck, S. 2011. Shrinking Cities in East Germany. Boekenplan. Maastricht.

Bontje, M. \& Musterd, S. 2012. "Understanding shrinkage in European regions", Built Environment, vol. 38:2, S. 153-161.

Boonstra, B. \& Boelens, L. 2011. "Self-organization in Urban Development: Towards a New Perspective on Spatial Planning”, Urban Research \& Practice, vol. 4:2, S. 99-112.

Bäcklund, P. \& Häkli, J. \& Schulman, H. (toim.) 2002. Osalliset ja osaajat. Kansalaiset kaupungin suunnittelussa. Gaudeamus, Helsinki.

Coleman, J. S. 1988. "Social Capital in the Creation of Human Capital", The American Journal of Sociology, vol. 94, S. 95-120.

Grossmann, K.; Bontje, M.; Haase, A. \& Mykhnenko, V. 2013. "Shrinking cities: Notes for the further research agenda", Cities, vol. 35, S. 221-225.

Elinympäristön tietopalvelu Liiteri. Suomen ympäristökeskus SYKE [viitattu: 24.11.2019]. Saantitapa: https://liiteri.ymparisto.fi/

Faludi, A. 2000. "The Performance of Spatial Planning", Planning Practice \& Research, vol. 15:4, S. 299-318.

Foster-Fishman, P. G.; Cantillon, D.; Pierce, S. J. \& Van Egeren, L. A. 2007. "Building an Active Citizenry. The Role of Neighborhood Problems, Readiness, and Capacity for Change", American Journal of Community Psychology, vol. $39: 1$, S. 91-106.

Haase, A.; Hospers, G. J.; Pekelsma, S. \& Rink, D. 2012. Shrinking Areas: Front-Runners in Innovative Citizen Participation. Haag: European Urban Knowledge Network.

Haase, A.; Nelle, A. \& Mallach, A. 2017. "Representing urban shrinkage - The importance of discourse as a frame for understanding conditions and policy", Cities, vol. 69, S. 95-101

Hart, R. A. 2013. Children's participation: The theory and practice of involving young citizens in community development and environmental care. Routledge.

Haukkala, T. 2011. Monipaikkaisuus - ilmiö ja tulevaisuus. Helsinki: Sitra. 56 s. Sitran selvityksiä 54. ISBN 978-951-563-770-3.

Heenan, D. A. 1991. The New Corporate Frontier: the Big Move to Small Town, USA. McGraw-Hill, New York.

Herrmann, J. L.; Shuster, W. D.; Mayer, A. L. \& Garmestani, A. S. 2016.

"Sustainability for shrinking cities", Sustainability, vol. 8:9. 
Herslund, L. 2012. "The rural creative class: counterurbanisation and entrepreneurship in the Danish countryside", Journal of the European Society for Rural Sociology, vol. 52:2, S. 235-255.

Hollander, J. B. 2009. Planning Shrinking Cities - Semantic Scholar. [Viitattu 25.3.2019]. Saatavissa:

http://www.academia.edu/download/44945581/Planning_Shrinking_Cities20160 421-3773-1byo52h.pdf

Hollander, J. B.; Pallagst, K. M.; Schwarz, T. \& Popper, F. J. 2009. „Planning shrinking cities", Progress in Planning, vol. 72:4, S. 195-250.

Horelli, L. 1994. Lasten näköinen elinympäristö: kokemuksia yhdyskuntasuunnittelun, ympäristökasvatuksen ja ehkäisevän sosiaalipolitiikan välisestä yhteistyöstä Kiteen Rantalan ala-asteella. Sosiaali- ja terveysministeriö: Ympäristöministeriö.

Häikiö, L. 2007. "Expertise, Representation and the Common Good: Grounds for Legitimacy in the Urban Governance Network", Urban Studies, vol. 44:11. S. 2147-2162.

Hyrkäs, E. 2009. Osaamisen johtaminen Suomen kunnissa. Acta Universitatis Lappeenrantaensis 338. Väitöskirja, Lappeenrannan teknillinen yliopisto.

Isola, A.-M.; Kaartinen, H.; Leemann, L.; Lääperi, R.; Schneider, T.; Valtari, S. \& Keto-Tokoi, A. 2017. Mitä osallisuus on? Osallisuuden viitekehystä rakentamassa. Työpaperi 33/2017. Terveyden ja hyvinvoinnin laitos, Helsinki.

Karjalainen, P. 2004. Uudenlaisia otteita ja kertaustyylejä. Lähiöuudistus 2000ohjelman arvioinnin loppuraportti. Suomen ympäristö 703. Ympäristöministeriö, Helsinki.

Kettunen, T. \& Kivinen, T. 2012. "Osallisuus hoitotyön kehittämisen suunnannäyttäjänä", Tutkiva Hoitotyö, vol. 10:4, S. 40-42.

Kohonen, K. \& Tiala, T. 2002. Johdanto. Teoksessa Kohonen, K. \& Tiala, T. (toim.). Kuntalaiset ja hyvä osallisuus. Lupaavia käytäntöjä kuntalaisten osallistumis- ja vaikuttamismahdollisuuksien edistämiseksi. Sisäasianministeriö ja Suomen Kuntaliitto, Helsinki, S. 5-9.

Koizumi, M. 2016. "Creativity in a shrinking society: A case study of the water and land Niigata art festival", Cities, vol. 56, S. 141-147.

Komulainen, M. 1998. Kylämaisema eläväksi! - asukaskeskeinen suunnittelu maaseudun kehittäjänä. Metsäntutkimuslaitos.

Kopomaa, T. \& Salin, O. 2018. "Osallistava asukasbudjetointi-ideoivat asukkaat kaupunkikehittämistyön osallisina", Yhdyskuntasuunnittelu, vol. 56:1, S. 11-29.

Kuntalaki 2015. [viitattu: 17.9.2020]. Saantitapa:

https://www.finlex.fi/fi/laki/ajantasa/2015/20150410.

Kuntien avainluvut. Tilastokeskus [viitattu: 24.11.2019]. Saantitapa: https://www.stat.fi/tup/alue/kuntienavainluvut.html\#?year=2019\&active1=SSS

Kurikka, P. 1999. Asuinkuntaansa tyytymätön nuori muuttaa. Teoksessa: Piipponen, S-L. (toim.). Tulevaisuuden haasteet ja kuntien strategiat. Kuntapuntari 5/99. Tilastokeskus, Vantaa 1999. 
Lampen, A. \& Ozwar, A. (edit.) 2008. Schrumpfende Städte - Ein Phänomen zwischen Antike und Moderne. Böhlau Verlag. Köln.

Liikenneministeriö 1999d. Henkilöliikennetutkimus 1998-1999.

Liikenneministeriön julkaisuja 43/1999.

Lund, V. \& Juujärvi, S. 2016. "Asukastyöpajat osallisuuden edistämisen välineenä Espoon keskuksessa", Yhdyskuntasuunnittelu, vol. 54:1, S. 43-58.

Maankäyttö- ja rakennuslaki 1999. [viitattu: 4.12.2019]. Saantitapa: http://www.finlex.fi/fi/laki/ajantasa/1999/19990132.

Manzini, E. 2015. Design, When Everybody Designs: An Introduction to Design for Social Innovation. Cambridge \& Lontoo: MIT Press.

Martinez-Fernandez, C.; Audirac, I.; Fol, S. \& Cunningham-Sabot, E. 2012. "Shrinking Cities: Urban Challenges of Globalization", International Journal of Urban and Regional Research, vol. 36:2, S. 213-225.

Martinez-Fernandez, C.; Weyman, T.; Fol, S.; Audirac, I.; Cunningham-Sabot, E.; Wiechmann, T. \& Yahagi, H. 2016. "Shrinking cities in Australia, Japan, Europe and the USA: From a global process to local policy responses", Progress in Planning, vol. 105, S. 1-48.

McGranahan, D.A.; Wojan, T.R. \& Lambert, D.M. 2011. "The rural growth trifecta: outdoor amenities, creative class and entrepreneurial context", Journal of Economic Geography, vol. 11:3, S. 529-557.

Meadowcroft, J. 1999. Planning for sustainable development: what can we learn about critics? Teoksessa Kenny, Michael \& Meadowcroft, James (toim.): Planning Sustainability. Routledge, London. S. 12-38.

Mononen, T.; Sairinen, R. \& Sihvonen, J. 2013. "Paikallinen tilaus kirkonkylien eheyttävän suunnittelun edellytyksenä", Alue ja ympäristö, vol. 42:1, S. 49-62.

Myrdal, G. 1957. Economic Theory and Underdeveloped Regions. Duckworth. London.

Myrskylä, P. 2012. Alueellisten työmarkkinoiden muutos. Työ ja yrittäjyys 1/2012. Työ ja elinkeinoministeriön julkaisuja.

Müller, D. \& Hall, C. 2004. The future of second home tourism. Teoksessa Hall, C. \& Müller, D. (toim.) Tourism, mobility and second homes. Between elite landscape and common ground. Channel View Publications, Clevedon, S. 273278.

Müller, D. 2014. Progress in second-home tourism research. Teoksessa Lew; Alan, A. \& Hall, C. Williams, A. (toim.) The Wiley Blackwell Companion to Tourism. Wiley-Blackwell.

Mäntysalo, R. 2006. Kunnan supistumiskehityksen hallinta-esimerkkinä Suomussalmi. Teoksessa: Hentilä, H.- L.; Mäntysalo, R. \& Soudunsaari, L. (toim.) Ekotehokkuus Supistuvissa ja Kasvavissa Taajamissa: Muuttuvan yhdyskuntarakenteen fyysinen, sosiaalinen ja ekologinen kestävyys. Oulu: Oulun yliopisto. Arkkitehtuurin osasto. Yhdyskuntasuunnittelun laboratorio. S. 80-87. 
Mönkkönen, M. 2006. Supistuminen, suunnittelu ja kestävyys kuntien haasteina. Teoksessa: Hentilä, H.- L.; Mäntysalo, R. \& Soudunsaari, L. (toim.) Ekotehokkuus Supistuvissa ja Kasvavissa Taajamissa: Muuttuvan yhdyskuntarakenteen fyysinen, sosiaalinen ja ekologinen kestävyys. Oulu: Oulun yliopisto. Arkkitehtuurin osasto. Yhdyskuntasuunnittelun laboratorio. S. 72-79.

Nivala, E. \& Ryynänen, S. 2013. Kohti sosiaalipedagogista osallisuuden ideaalia. Sosiaalipedagoginen aikakausikirja, vuosikirja 14, S. 11-41.

Nonaka, I. \& Takeuchi, H. 1995. The Knowledge-Creating Company: How Japanese Companies Create the Dynamics of Innovation, Oxford University Press, New York.

Nurmio, K.; Rehunen, A.; Antikaine, J.; Laasonen, V.; Helminen, V.; Vartiainen, P. \& Soininvaara, I. 2017. Toiminnalliset alueet ja kasvuvyöhykkeet Suomessa, Valtioneuvoston kanslia, $121 \mathrm{~s}$. Valtioneuvoston selvitys- ja tutkimustoiminnan julkaisusarja 50/2017.

Oswalt, P. \& Rieniets, T. 2006. Atlas of Shrinking Cities. Hatje Cantz. Ostfildern.

Palttila, Y. 2002. "Asenteet maaseutua kohtaan ja maaseudulle muutto Suomessa. Kirjallisuuskatsaus uusimpiin tutkimustuloksiin", Maaseudun uusi aika, vol. 10:1, S. 8-17.

Parjanen, S.; Hennala, L.; Hyypiä, M. \& Martikainen, S.-J. 2016 "Sosiaalisesti kestävä innovointi - Asuinympäristöjen kehittäjien näkemyksiä asukkaiden osallistamisesta", Yhdyskuntasuunnittelu, vol. 54:4.

Pitkänen, K. \& Vepsäläinen, M. 2008. "Foreseeing the future of second home tourism. Case Finnish media and policy discourse", Scandinavian Journal of Hospitality and Tourism, vol. 8:1, S. 1-24.

Pitkänen, K. 2011. Mökkimaisema muutoksessa. Kulttuurimaantieteellinen näkökulma mökkeilyyn. Publications of the University of Eastern Finland. Dissertations in Social Sciences and Business Studies No 31. University of Eastern Finland, Joensuu.

Popper, D.E. \& Popper, F.J. 2002. "Small can be beautiful: coming to terms with decline”, Planning, vol. 68:7, S. 20-23.

Rehunen, A.; Rantanen, M.; Lehtola, I. \& Hiltunen, M.J. (toim.) 2012. Palvelujen saavutettavuus muutoksessa - Maaseudun vakituisten ja vapaa-ajan asukkaiden palveluympäristön kehityssuunnat ja uudet mahdollisuudet. Helsingin yliopisto, Ruralia-instituutti, raportteja 88.

Raatikainen, S. 2004. Pienenevän infrastruktuurin suunnittelu ja hallinta. Acta Universitatis Ouluensis Technica, C 199, Oulu.

Roca, Z. (toim.) 2013. Second home tourism in Europe: lifestyle, issues and policy responses. Ashgate, Farnham.

Ročak, M.; Hospers, G.; Reverda, N.; Ročak, M.; Hospers, G. \& Reverda, N. 2016. "Searching for Social Sustainability: The Case of the Shrinking City of Heerlen, The Netherlands", Sustainability (Switzerland), vol. 8:4, S. 382.

Rönkkö, E. 2010. Maaseudun kirkonkylien ja kulttuuriympäristöjen muutos 1970-luvun lopulta 2010-luvulle. Suomalainen maaseututaajama muutospaineessa. Teoksessa: Aarrevaara, E. (toim.) (2015) Suomalainen 
maaseututaajama muutospaineessa - Suomalainen maaseututaajama 2010luvulla -tutkimushankkeen loppuraportti. Lahden ammattikorkeakoulu. $164 \mathrm{~s}$. Lahden ammattikorkeakoulu Oy:n julkaisusarja, osa 3. S. 20-34.

Sallinen, S.; Aronen, K.; Asikainen, J.; Huovinen, J.; Kallio-Savela, M.; Kurikka, P.; Kämppi, M.; Laine, R.; Paahtama, S.; Punnonen, H.; Salminen, H.; Siltala, S.; Sjöholm, K.; Tuimala, A.; Vuorento, R.; Winqvist, D.; Yli-Suomu, R.-M. \& Åström, C. 2011. Elinvoimainen kunta. Helsinki: Suomen Kuntaliitto.

Selkämaa, K. 2016. Sosiaalisen median rooli kunnan viestinnässä. Opinnäytetyö. Satakunnan ammattikorkeakoulu, Liiketalouden koulutusohjelma.

Sihvo, S.; Isola, A.-M.; Kivipelto, M.; Linnanmäki, E.; Lyytikäinen, M. \& Saino, S. 2018. Asiakkaiden osallistumisen toimintamalli. Loppuraportti. Sosiaali- ja terveysministeriön raportteja ja muistioita 16:2018, Helsinki.

Staffans, A. 2004. Vaikuttavat asukkaat: Vuorovaikutus ja paikallinen tieto kaupunkisuunnittelunhaasteina. YTK julkaisuja A29. Teknillinen korkeakoulu, Espoo.

Strandell, A. 1999. Asukasbarometri 1998 - Asukaskysely suomalaisista asuinympäristöistä. Ympäristöministeriö, Helsinki. Suomen ympäristö 343.

Strandell, A. 2005. Asukasbarometri 2004 - Asukaskysely suomalaisista asuinympäristöistä. Ympäristöministeriö, Helsinki. Suomen ympäristö 746.

Strandell, A. 2011. Asukasbarometri 2010 - Asukaskysely suomalaisista asuinympäristöistä. Suomen ympäristökeskus, Helsinki. Suomen ympäristö $31 / 2011$.

Strandell, A. 2017. Asukasbarometri 2016 - Kysely kaupunkimaisista asuinympäristöistä. Suomen ympäristökeskus, Helsinki. Suomen ympäristökeskuksen raportteja 19/2017.

Sulzer, J. (edit.) 2007. Revitalisierender Städtebau: Werte. TUDpress. Dresden.

Suomen virallinen tilasto. Käsitteet. Taajama [Verkkoaineisto]. [Viitattu 9.8.2020]. Saatavissa: https://www.stat.fi/meta/kas/taajama.html\#tab2.

Suomen virallinen tilasto (SVT): Rakennukset ja kesämökit [verkkojulkaisu]. ISSN=1798-677X. 2018, Kesämökit 2018. Helsinki: Tilastokeskus [viitattu: 6.12.2019].

Saantitapa: http://www.stat.fi/til/rakke/2018/rakke_2018_2019-05-

21_kat_001_fi.html

Suomen virallinen tilasto (SVT): Väestöennuste [verkkojulkaisu]. ISSN=1798-5137. 2019. Helsinki: Tilastokeskus [viitattu: 8.11.2019]. Saantitapa: http://www.stat.fi/til/vaenn/2019/vaenn_2019_2019-0930_tie_001_fi.html

Suomen virallinen tilasto (SVT): Väestöennuste [verkkojulkaisu]. ISSN=1798-5137. 2015. Helsinki: Tilastokeskus [viitattu: 8.11.2019]. Saantitapa: http://www.stat.fi/til/vaenn/2015/vaenn_2015_2015-1030_tie_001_fi.html

Suomen virallinen tilasto (SVT): Väestön ennakkotilasto [verkkojulkaisu]. ISSN=1798-8381. lokakuu 2019. Helsinki: Tilastokeskus [viitattu: 26.11.2019]. Saantitapa: http://www.stat.fi/til/vamuu/2019/10/vamuu_2019_10_2019-1126_tie_001_fi.html 
Suomen virallinen tilasto (SVT): Väestörakenne [verkkojulkaisu]. ISSN=17975379. 2019. Helsinki: Tilastokeskus [viitattu: 16.8.2020].

Saantitapa: http://www.stat.fi/til/vaerak/2019/vaerak_2019_2020-0324_tie_001_fi.html

Taylor, N. 1998. Urban Planning Theory Since 1945. London, Sage.

Tietjen, A. \& Jørgensen, G. 2016. "Translating a wicked problem: A strategic planning approach to rural shrinkage in Denmark", Landscape and Urban Planning, vol. 154, S. 29-43.

Tuomi, J. \& Sarajärvi, A. 2002. Laadullinen tutkimus ja sisällönanalyysi. Helsinki: Tammi. $158 \mathrm{~s}$. ISBN 951-26-4856-3.

Valtiovarainministeriö 2018. Millaista monipaikkaisuutta Suomeen - Selvitys kaksoiskuntalaisuudesta. Valtiovarainministeriö. $74 \mathrm{~s}$. Valtiovarainministeriön julkaisu 3/2018. ISBN 978-952-251-926-9

Vepsäläinen, M.; Strandell, A. \& Pitkänen, K. 2015. "Muuttuvan vapaa-ajan asumisen hallinnan haasteet kunnissa", Yhdyskuntasuunnittelu, 2015:2 vol. 53.

Verwest, F.; van Dam, F. \& Daalhuizen, F. 2010. "New living: the shrinking countryside considers itself well off", Geografie, vol. 21, S. 42-45.

Victor, B. \& Boynton, A. 1998. Invented Here: Maximizing Your Organization's Internal Growth and Profitability. A Practical Quide to Transforming Work, Boston, Mass.: Harvard Business School Press.

Visvizi, A., \& Lytras, M. 2018. "It's not a fad: Smart cities and smart villages research in European and global contexts", Sustainability, vol. 10:8.

Wagenaar, H. 2007. "Governance, complexity, and democratic participation. How citizens and public officials harness the complexities of neighborhood decline", The American Review of Public Administration, vol. 37:1, S. 17-50.

Wiechmann, T. 2007. What are the problems of shrinking cities? Lessons learned from an international comparison. Teoksessa: Wiechmann, T. (toim.). The future of shrinking cities - Problems, patterns and strategies of urban transformation in a global context. Berkeley, CA: Studies, Center for Global Metropolitan Development, Institute of Urban and Regional Network, and the Shrinking Cities International Research, S. 5-16. 